\title{
Enzyme system in rat leucocyte granules which degrades insoluble collagen
}

\author{
A. J. ANDERSON \\ Lilly Research Centre Ltd., Erl Wood Manor, Windlesham, Surrey
}

It is now well documented that lysosomal enzymes, most with optimum activities in the $\mathrm{pH}$ range 3 to 6 , contribute to connective tissue breakdown in rheumatoid arthritis and other inflammatory diseases. Some of these enzymes may act extracellularly, for instance in avascular inflamed cartilage, since lactic acid, formed by anaerobic glycolysis in chondrocytes, may diffuse out and become concentrated around these cells to give a sufficiently low pH (Bollet, 1969). Furthermore, in tissues containing a high proportion of acid mucopolysaccharides, comparatively acid conditions may exist locally adjacent to dissociated carboxyl and sulphate groups. However, it is unlikely that vascular inflamed tissues, containing considerably less mucopolysaccharides than cartilage, will become similarly acid.

There is therefore some uncertainty regarding the extracellular activity of the acidophilic lysosomal enzymes in vascular tissue, and a study of cellular enzymes active under neutral conditions may be more relevant when considering connective tissue breakdown during the earlier stages of inflammation.

This paper reports an enzyme system in rat leucocyte granules which releases soluble hydroxyproline-containing products from insoluble collagen over a wide $\mathrm{pH}$ range, with maximum activities at $\mathrm{pH}$ values $3 \cdot 5$ and $8 \cdot 4$. A preliminary account of part of this work has been published (Anderson, 1971).

\section{Materials and methods}

The following substances were used: saline, 0.9 per cent. $(w / v) ~ N a C l$ in water; glycogen (oyster), from Koch-Light Laboratories, Colnbrook, Bucks; L-cysteine hydrochloride, from British Drug Houses Ltd., Poole, Dorset; D-penicillamine from Dista Products Ltd., Liverpool; phenylbutazone, from Geigy Pharmaceutical Industries. Homogenization was carried out in a Potter-Elvehjem homogenizer ( $16 \mathrm{~mm}$. bore) cooled in ice-water mixture.
Preparation of a suspension of rat peritoneal leucocytes Male Wistar Lodgemoor rats of 200-250 g. were injected intraperitoneally with $2 \mathrm{ml}$. glycogen solution (1 per cent., $\mathrm{w} / \mathrm{v}$, in saline). After $4 \mathrm{hrs}$ the animals were killed by $\mathrm{CO}_{2}$ inhalation and injected intraperitoneally with $10 \mathrm{ml}$. saline (containing 100 units heparin). After the abdomen had been massaged for 2 min. it was opened and the washings aspirated. The abdominal cavity was rinsed with a further $2 \mathrm{ml}$. heparin-saline mixture and the combined washings centrifuged ( 250 G., 5 min.). The separated leucocytes were washed once with saline, and then re-suspended in saline. The average yield was $25 \times 10^{6}$ leucocytes from each rat, consisting of neutrophils (55 per cent.) and lymphocytes (38 per cent.) with monocytes and eosinophils but no basophils.

Isolation of enzymes from whole leucocytes (WL fraction) To the leucocyte suspension Triton-X-100 (final concentration $0 \cdot 2$ per cent., $v / v$ ) was added to lyse the membranes of the cells and granules. The mixture was homogenized for $2 \mathrm{~min}$. and centrifuged $(2,000 \mathrm{G}$., $10 \mathrm{~min}$.). The supernatant fluid was termed the whole leucocyte fraction (WL).

Isolation of enzymes from leucocyte granules (LG fraction) The leucocyte suspension was centrifuged ( $250 \mathrm{G}$., $5 \mathrm{~min}$.) and the cells suspended in $0.34 \mathrm{M}$ sucrose. The outer membranes of the leucocytes were ruptured, by forcing this suspension twenty times through the grid of a Millipore filter unit, with no filter-pad inserted (Weissmann, Spilberg, and Krakauer, 1969). The mixture was centrifuged (400 G., $10 \mathrm{~min}$.) and the supernatant fluid, containing liberated leucocyte granules in suspension, was stored at $4^{\circ} \mathrm{C}$. The sedimented material was re-suspended in $0.34 \mathrm{M}$ sucrose and the procedure repeated seven times. The eight supernatant fluids were combined and centrifuged $(15,000 \mathrm{G}$., $20 \mathrm{~min}$.). Membranes of the sedimented granules were then lysed by adding $0.34 \mathrm{M}$ sucrose containing 0.2 per cent. (v/v) Triton-X-100. The mixture was stood at $4^{\circ} \mathrm{C}$. for $2 \mathrm{hrs}$, homogenized for $2 \mathrm{~min}$. to ensure complete membrane lysis, and finally centrifuged $(2,000 \mathrm{G}$., $10 \mathrm{~min}$.). The supernatant fluid, containing the granular enzymes, was stored at $4^{\circ} \mathrm{C}$., and the sedimented material was re-suspended in the sucrose-Triton mixture and homogenized twice more, centrifuging each time. The 
supernatant fluids were combined and termed the leucocyte granular fraction (LG). Estimation of $\beta$ glucuronidase, as described by Anderson (1968), showed that 54 per cent. of the total activity was recovered in the LG fraction.

\section{Estimation of collagen-solubilizing enzymes}

The ability of the enzymes in the whole leucocyte (WL) fraction and in the leucocyte granular (LG) fraction to 'solubilize' insoluble collagen over the $\mathrm{pH}$ range 1.6 to 10.0 was determined. The method and buffer solutions used are described elsewhere (Anderson, 1969). Incubation was for $3 \mathrm{hrs}$ at $37^{\circ} \mathrm{C}$.

To $0.4 \mathrm{ml}$. of the WL fraction (obtained from $19 \times 10^{6}$ leucocytes), or to $0.8 \mathrm{ml}$. of the LG fraction (obtained from $40 \times 10^{6}$ leucocytes), were added $2 \mathrm{ml}$. of buffer and $0.5 \mathrm{ml}$. of collagen suspension $(10 \mathrm{mg}$.). To allow for any hydroxyproline-containing proteins in the leucocyte enzyme fractions, a blank tube was included which contained $0.5 \mathrm{ml}$. saline in place of collagen suspension. A further blank tube, to allow for the slight solubility of collagen in the buffers used, consisted of an equivalent volume of saline in place of the enzyme fraction. Enzyme activity was assessed as the amount of soluble hydroxyproline-containing products released from insoluble collagen, expressed as $\mu \mathrm{g}$. hydroxyproline.

Effect of various substances and of heat on the collagensolubilizing enzymes

Using essentially the same method, the effects on these enzymes at $\mathrm{pH} 3.5$ and 8.4 of normal rat serum $(6.3$ per cent., $v / v)$, cysteine $(10 \mathrm{mM})$, penicillamine $(10 \mathrm{mM})$, and phenylbutazone $(2 \mathrm{mM})$ were determined. Penicillamine was added as a solution in either $0.2 \mathrm{M}$-acetate buffer (pH 3.5) or $0.2 \mathrm{M}$-phosphate buffer $(\mathrm{pH} \mathrm{8.4)}$. Cysteine was added as a solution in water, after adjustment of the solution to $\mathrm{pH} 3 \cdot 5$ or $8 \cdot 4$ by addition of $1 \mathrm{~N}-\mathrm{NaOH}$. Phenylbutazone was added as a solution in ethanol. In each case, blanks consisting of the solvent only were included in the estimations.

Collagen-solubilizing activity was determined after subjecting the WL fraction to $56^{\circ} \mathrm{C}$. for $10 \mathrm{~min}$. or to $100^{\circ} \mathrm{C}$. for $10 \mathrm{~min}$.

\section{Results}

Solubilization of insoluble collagen by rat leucocyte enzymes over the $\mathrm{pH}$ range 1.6 to 10.0 is shown in the Figure. The amount of hydroxyproline-containing products released in soluble form indicates the activity of the enzymes present in the whole leucocytes (WL fraction) and in the leucocyte granules (LG fraction). The effect of various substances and of heat treatment on the activities of this enzyme system are shown in the Table.

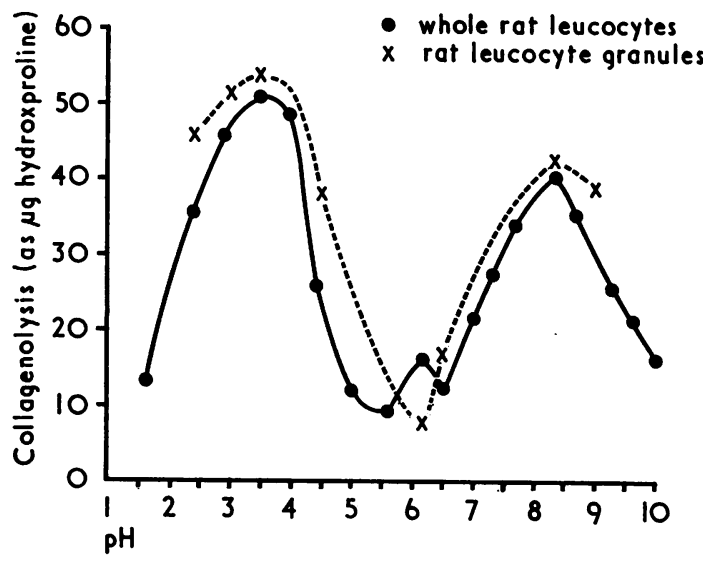

FIG. Effect of pH on collagen-solubilizing enzymes. Each curve represents the average of two experiments

\section{Discussion}

Mammalian collagenases, which cleave native helical collagen to soluble peptides at neutral $\mathrm{pH}$, have been detected in human rheumatoid synovial fluid, although not in normal fluid (Harris, DiBona, and Krane, 1969; Harris, Evanson, DiBona, and Krane, 1970). Rheumatoid synovial fluid also contains collagen fibrils, probably derived from collagenase attack on articular cartilage (Kitridou, McCarty, Prockop, and Hummeler, 1969). Collagenases, believed not to be lysosomal, are present in cultures of human rheumatoid synovial membrane (Evanson, Jeffrey, and Krane, 1968). Human polymorphonuclear leucocyte lysosomes also contain a collagenase (Lazarus, Brown, Daniels, and Fullmer, 1968), which can degrade glomerular

Table Effect of various substances and heat treatment on rat leucocyte enzymes which 'solubilize' insoluble collagen

\begin{tabular}{|c|c|c|c|c|}
\hline \multirow[t]{2}{*}{ Treatment } & \multirow{2}{*}{$\begin{array}{l}\text { Enzyme } \\
\text { fraction }\end{array}$} & \multicolumn{3}{|c|}{ Enzyme inhibition or activation (per cent.) } \\
\hline & & pH 3.5 & pH 6.2 & pH 8.4 \\
\hline $\begin{array}{l}\text { L-cysteine }(10 \mathrm{mM}) \\
\text { D-penicillamine }(10 \mathrm{mM}) \\
\text { Phenylbutazone }(2 \mathrm{mM}) \\
\text { Normal rat serum }(6 \cdot 3 \text { per cent., } \mathrm{v} / \mathrm{v})\end{array}$ & $\begin{array}{l}\text { LG } \\
\text { LG } \\
\text { WL } \\
\text { WL }\end{array}$ & $\begin{array}{l}+136 \\
+16 \\
+50 \\
-\quad 5\end{array}$ & $\begin{array}{l}\text { N.D. } \\
\text { N.D. } \\
\text { N.71 } \\
\text { N.D. }\end{array}$ & $\begin{array}{l}-16 \\
+4 \\
-50 \\
-66\end{array}$ \\
\hline Heat for $10 \mathrm{~min} .\left\{\begin{array}{l}56^{\circ} \mathrm{C} \text {. } \\
100^{\circ} \mathrm{C} \text {. }\end{array}\right.$ & WL & $\begin{array}{l}-24 \\
-61\end{array}$ & $\begin{array}{l}\text { N.D. } \\
\text { N.D. }\end{array}$ & $\begin{array}{l}-11 \\
-81\end{array}$ \\
\hline
\end{tabular}

N.D. = not done

Negative and positive values per cent. indicate inhibition and enhancement of enzymic activity, respectively. WL and LG refer to the extracts of whole leucocytes (WL fraction) and to the extract of leucocyte granules (LG fraction). 
basement membrane in vitro and which rapidly produces vascular injury when injected into animals (Janoff and Zeligs, 1968).

The present paper describes an enzyme system in rat leucocyte granules that can solubilize insoluble trypsin-resistant tendon collagen (Anderson, 1969), with maximum activities at $\mathrm{pH} 3.5$ and $8 \cdot 4$. It is not known whether these enzymes break covalent bonds within the collagen molecule, the latter enzyme functioning as a collagenase, or whether they act by hydrolysing interfibrillar nonhelical material (telopeptides) cross-linking the soluble tropocollagen units. Proteases with similar $\mathrm{pH}$ optima have been reported in granules from human leucocytes (Stiles and Fraenkel-Conrat, 1968) and platelets (Nachman and Ferris, 1968), but their action on insoluble collagen was not investigated.

Normal rat paws contain a collagen-solubilizing enzyme, active at pH 3.5 and much more abundant in paws from adjuvant arthritic rats (Anderson, 1970). Similar enzymes active under acid conditions are present in rat liver lysosomes (Anderson, 1969) and in rat inflamed tissue (Bazin and Delaunay, 1966); both activities are enhanced by cysteine, but only the former is inhibited by phenylbutazone. The rat leucocyte enzyme, optimally active at $\mathrm{pH}$ 8.4 and absent from rat liver (Anderson, 1969), was inhibited by phenylbutazone and normal rat serum, but was unaffected by cysteine. A third collagen-solubilizing enzyme, absent from the granular fraction and maximally active at $\mathrm{pH} 6 \cdot 2$, was detected as a minor leucocyte component.

As discussed elsewhere (Anderson, 1968), inhibition of lysosomal hyaluronidase and $\beta$-glucuronidase by phenylbutazone may contribute in vivo to its anti-inflammatory properties by protecting tissue mucopolysaccharides. Since phenylbutazone also inhibits the two collagen-solubilizing enzymes described here, it could also protect cartilage and basement membrane collagen (Kefalides and Denduchis, 1969) from enzyme attack in vivo.

Leucocyte and tissue cell granules also contain enzymes which can degrade noncollagenous tissue components at near-neutral pH values (Mahadevan and Tappel, 1967; Weissmann and Spilberg, 1968; Stiles and Fraenkel-Conrat, 1968; Fehr, LoSpalluto, and Ziff, 1969; Davies, Krakauer, and Weissmann, 1970). Several workers, including Dingle and Fell and their colleagues (Fell, 1969) and Evanson (1971), have suggested that an early stage in inflammation is the partial extracellular digestion of connective tissue components by cellular enzymes active at neutrality. This is followed by a second stage, when the breakdown products are endocytosed and digested under acid conditions within the lysosomal system of the cell.

The enzymes in rat leucocytes which can attack collagen at neutral $\mathrm{pH}$ could contribute to the initial extracellular stage and might be a major cause of tissue destruction. A study of these enzymes may suggest effective means of controlling inflammation.

\section{Summary}

An enzyme system in rat peritoneal leucocyte granules solubilizes insoluble collagen in vitro from $\mathrm{pH} 1.6$ to $10 \cdot 0$, with maximum activities at $\mathrm{pH}$ 3.5 and $8 \cdot 4$. The former enzyme is similar to one detected previously in a rat liver lysosome-rich fraction, activities being enhanced by cysteine and inhibited by phenylbutazone. The latter leucccyte enzyme, absent from rat liver, was inhibited by phenylbutazone and normal rat serum. Part of the clinical effectiveness of phenylbutazcne could result from inhibition of these granular enzymes in vivo, thus protecting collagen in cartilage and basement membranes from direct attack at physiological $\mathrm{pH}$.

I thank Dr. W. E. Brocklehurst for his interest in this work and for criticism of the manuscript. I am grateful to Mrs. L. Berry for valuable technical assistance.

\section{References}

ANDerson, A. J. (1968) Biochem. Pharmacol., 17, 2253 (The effect of anti-inflammatory drugs on the enzymic activity of a rat liver granular fraction which increases vascular permeability).

- (1969) Biochem. J., 113, 457 (Effects of lysosomal collagenolytic enzymes, anti-inflammatory drugs and other substances on some properties of insoluble collagen).

(1970) Ann. rheum. Dis., 29, 307 (Lysosomal enzyme activity in rats with adjuvant-induced arthritis).

(1971) Z. klin. Chem., p. 66, Proceedings of 'Second European Symposium on Connective Tissue Research', Hanover (Degradation of insoluble collagen by rat leucocytes).

Bazin, S., ANd Delaunay, A. (1966) Ann. Inst. Pasteur, 110, 192 (Caractères de cathépsines collagénolytiques présentes dans les tissus enflammés du rat).

Bollet, A. J. (1969) Arthr. and Rheum., 12, 152 (An essay on the biology of osteoarthritis).

Davies, P., Krakauer, K., and Weissman, G. (1970) Nature (Lond.), 228, 761 (Subcellular distribution of neutral protease and peptidases in rabbit polymorphonuclear leucocytes).

Evanson, J. M. (1971) Z. klin. Chem., p. 65. Proceedings of 'Second European Symposium on Connective Tissue Research', Hanover (Action of mammalian collagenases). 
—, JefFreY, J. J., AND KRANe, S. M. (1968) J. clin. Invest., 47, 2639 (Studies on collagenase from rheumatoid synovium in tissue culture).

Fehr, K. LoSpalluto, J., AND ZIFF, M. (1969) Fed. Proc., 28, 496 (Digestion of immunoglobulin G by lysosomal enzymes).

FrL, H. B. (1969) Ann. rheum. Dis., 28, 213 (Heberden Oration, 1968. Role of biological membranes in some skeletal reactions).

Harris, E. D., DiBona, D. R., AND Krane, S. M. (1969) J. clin. Invest., 48, 2104 (Collagenases in human synovial fluid).

-, Evanson, J. M., DiBona, D. R., And Krane, S. M. (1970) Arthr. and Rheum., 13, 83 (Collagenase and rheumatoid arthritis).

JANOFF, A., AND ZeLIGS, J. D. (1968) Science, 161, 702 (Vascular injury and lysis of basement membrane in vitro by neutral protease of human leucocytes).

Kefalmids, N. A., AND Denduchis, B. (1969) Biochemistry, 8, 4613 (Structural components of epithelial and endothetial basement membranes).

Kitridou, R., McCarty, D. J., Prockop, D. J., ANd Hummeler, K. (1969) Arthr. and Rheum., 12, 580 (Identification of collagen in synovial fluid).

LazArus, G. S., Brown, R. S., Danizls, J. R., AND Fullmer, H. M. (1968) Science, 159, 1483 (Human granulocyte collagenase).

Mahadevan, S., AND TAPPEl, A. L. (1967) J. biol. Chem., 242, 4568 ( $\beta$-aspartyl-glucosylamine amido hydrolase of rat liver and kidney).

NACHMAN, R. L., AND FerRIS, B. (1968) J. clin. Invest., 47, 2530 (Studies on human platelet protease activity).

Stiles, M. A., AND Fraenkel-ConRat, J. (1968) Blood, 32, 119 (Subcellular distribution of human leucocytic cathepsins).

Weissman, G., AND SPILBerg, I. (1968) Arthr. and Rheum., 11, 162 (Breakdown of cartilage proteinpolysaccharide by lysosomes).

- — - AND KRAKAUER, K. (1969) Ibid., 12, 103 (Arthritis induced in rabbits by lysates of granulocyte lysosomes). 